\title{
JAK POWSTAŁA AUTOSTRADA A4?
}

\section{Janusz Kaliński}

Szkoła Główna Handlowa w Warszawie

\author{
ABSTRACT \\ HOW WAS THE POLISH A4 MOTORWAY BUILT?
}

The Polish A4 motorway, with a length of $672 \mathrm{~km}$, runs from the border with Germany via Wrocław, Katowice, Kraków and Rzeszów to the border with Ukraine. The construction of the motorway, interrupted by political, economic and technical factors, stretched over 80 years. Before 1945, it had been built as a German autobahn connecting Berlin with Upper Silesia. After the war, already within the Polish borders, it initially served to connect Lower and Upper Silesia with Kraków, and then became a transit route between Germany and Ukraine. The construction of the final stretch of the motorway was strongly associated with the political changes in Europe after 1989, and especially with the Polish accession to the European Union. European funds had a major impact on the acceleration of investment at the turn of the century.

Key words: Poland, A4 motorway, road transport, EU funds.

Słowa kluczowe: Polska, autostrada A4, transport drogowy, fundusze UE.

Dnia 20 lipca 2016 roku, w wyniku oddania do użytku 41-kilometrowego odcinka Rzeszów - Jarosław, powstała możliwość przejechania na całej długości autostradą A4, łączącą zachodnią i wschodnią granicę Polski. Najdłuższa w Polsce, licząca $672 \mathrm{~km}$, autostrada stanowi bardzo ważny krok na drodze do zrealizowania planu budowy sieci ok. $2000 \mathrm{~km}$ nowoczesnych dróg samochodowych. Przebiega przez silnie zurbanizowane i uprzemysłowione regiony Polski południowej, stanowi ważny korytarz tranzytowy między Niemcami a Ukrainą i łączy się z autostradami A1, A8 i A18. Przerywana czynnikami politycznymi, ekonomicznymi i technicznymi budowa autostrady rozciągnęła się na ponad 80 lat, co stanowi ewenement w historii budownictwa drogowego. Warto zatem prześledzić jej trudne losy realizacyjne, których początki sięgają lat 30. XX wieku. 


\section{DZIEDZICTWO HITLEROWSKICH NIEMIEC I POLSKI LUDOWEJ}

Odcinki współczesnej A4 znalazły się w planach stworzenia sieci autostrad kreślonych przez władze hitlerowskich Niemiec. Ich budowa była elementem interwencjonizmu państwowego i przygotowań wojennych, w których zakładano wykorzystanie nowoczesnych dróg samochodowych do szybkiego przerzutu wojsk. Zachodni korytarz dzisiejszej A4 wyznaczył niemiecki projekt Reichsautobahn Berlin - Bytom. Program autostradowy, podjęty w latach 30 ., realizowano także w początkowych latach II wojny światowej, powszechnie wykorzystując jeńców niemieckich obozów pracy. W rezultacie, w latach 1934-1943, powstały dwujezdniowe odcinki Krzyżowa - Wrocław $(99 \mathrm{~km})$ oraz jednojezdniowe Wrocław - Brzeg (ok. $41 \mathrm{~km})$ i Nogowczyce - Gliwice (ok. $37 \mathrm{~km})^{1}$. Pojedyncze obiekty autostradowe powstały między Zgorzelcem a Krzyżową, na planowanej Reichsautobahn Drezno - Wrocław. Część autostrad, szczególnie budowanych podczas wojny, cechowała niska jakość i niedostosowanie do intensywnego ruchu kołowego. Między Krzyżową a Wrocławiem płyty betonowe ułożono na gruncie gliniastym. W warunkach rosnącego natężenia ruchu płyty popękały i zostały wciśnięte, tworząc uskoki („schody”). Po wojnie, po przejęciu terenów Dolnego i Górnego Śląska przez Polskę, na skutek niedostatecznych remontów, szczególnie obiektów inżynierskich, stopniowo wyłączano z ruchu poszczególne odcinki, przekształcając autostrady w drogi jednojezdniowe, które ulegały dalszej degradacji ${ }^{2}$.

W pierwszych powojennych projektach autostradowych, które powstały w Głównym Urzędzie Planowania Przestrzennego w 1948 roku, przewidywano połączenie odcinków poniemieckich (nazywanych Autostradą Śląską) z nową autostradą Katowice - Kraków, co umożliwiłoby lepsze powiązanie Dolnego i Górnego Śląska z Małopolską. Należy dodać, że był to fragment proponowanej w latach 30 . przez polskich specjalistów autostrady Katowice - Lwów. Przypadający na lata 50. okres intensywnej industrializacji Polski, mimo rosnących potrzeb transportowych, nie sprzyjał realizacji projektów autostradowych. Ich plany pojawiły się w 1963 roku w ramach prac Rady Motoryzacyjnej przy Radzie Ministrów. Zakładały wybudowanie $1400 \mathrm{~km}$ autostrad, w tym przedłużenie projektowanej autostrady południowej na wschód od Krakowa do granicy z radziecką Ukrainą ${ }^{3}$.

Rozwinięty korytarz autostrady A4 znalazł się w koncepcjach Centralnego Biura Projektów i Studiów Dróg, Mostów i Lotnisk z 1969 roku. Zaproponowany przez Biuro kierunkowy projekt sieci autostrad do 2000 roku, o łącznej długości $2930 \mathrm{~km}$, obejmował m.in. autostradę (Lwów) Rzeszów - Kraków - Katowice - Wrocław

1 C. Reichel, Drogi na Dolnym Śląsku. Takie byly początki, „Polskie Drogi” 1995, nr 8, s. 7; Autobahn Online, http://www.autobanhn-online.de/ausserdeutschestrecken.html [dostęp: 15.05.2015].

2 K. Majchrzak, M. Uchnyst, Modernizacja autostrady a-4 odcinek Legnica - Wroctaw, „Drogownictwo" 1995, nr 5, s. 132-135.

3 Uchwaly IV-go Polskiego Kongresu Drogowego, „Wiadomości Drogowe” 1938, nr 132-133, s. 167; Studium Planu Krajowego II, Warszawa 1948, s. 54; Prace Rady Motoryzacyjnej 1958-1964, Warszawa 1965, s. 112. 
(Berlin) z odgałęzieniem Bolesławiec - Zgorzelec (Drezno). Na odcinku wschodnim autostrada miała przekraczać granicę w rejonie Przemyśla. Równocześnie przystąpiono do opracowania studiów techniczno-ekonomicznych, m.in. dla odcinka autostradowego Kraków - Katowice. Podstawą studiów były badania ruchu istniejącego, prognoza ruchu na okres 20-letni i planowany rozwój regionów, lokalizacja nowych oraz rozbudowa istniejących ośrodków miejskich, przemysłowych i turystycznych, jak też rozwój innych systemów komunikacyjnych ${ }^{4}$.

Rada Motoryzacyjna postulowała, aby podstawowym kryterium projektowania autostrad była intensywność ruchu. Zgodnie z tą przesłanką Centralny Zarząd Dróg Publicznych przygotował w 1966 roku studium ruchowe i ekonomiczne, zbudowania od podstaw, autostrady Górnośląski Okręg Przemysłowy (GOP) - Kraków, łączącej Gliwice z Krakowem. Wybór tego odcinka podyktowany był dużym natężeniem ruchu i wyczerpaniem się możliwości zwiększenia przepustowości istniejących powiązań drogowych między Katowicami a Krakowem. Rada Motoryzacyjna po zapoznaniu się ze studium postanowiła wystąpić do rządu o zgodę na podjęcie prac przygotowawczych do budowy autostrady. Przewidywano, że budowa drogi rozpocznie się w 1974 roku i potrwa trzy lata ${ }^{5}$.

Objęcie władzy przez Edwarda Gierka przyniosło szereg decyzji inwestycyjnych o charakterze strategicznym, w tym przyjęcie przez rząd w 1972 roku Kierunkowego uktadu perspektywicznego sieci autostrad. Jego finansowanie oparto na środkach budżetowych z możliwością powołania Funduszu Autostradowego czerpiącego dochody z opłat paliwowych. Odpowiednia ustawa powstała dopiero w 1989 roku, co oznaczało, że budowa autostrad w PRL zależna była od stanu budżetu państwa ${ }^{6}$. Kierunkowy układ zakładał budowę dwóch autostrad południe - północ (granica z Czechosłowacją - Katowice - Łódź - Torun - Grudziądz - Gdańsk i granica z Czechosłowacją - Wrocław - Poznań - Bydgoszcz - Grudziądz), autostrad Wrocław - Łódź i Kraków - Kielce - Warszawa - Toruń oraz dwóch autostrad wschód - zachód (Terespol - Warszawa - Łódź - Poznań - Świecko i granica wschodnia - Rzeszów - Kraków - Katowice - Wrocław - Trzebiel - granica zachodnia). Oznaczało to skierowanie południowej autostrady wschód - zachód od Krzyżowej w kierunku Berlina. Do 1980 roku zamierzano zrealizować na tej autostradzie odcinki Gliwice - Kraków - Tarnów oraz po jednej jezdni między Przylesiem a Nogowczycami i Krakowem a Tarnowem. Jednak już w drugiej połowie 1976 roku, kiedy z całą siłą wystąpiły negatywne skutki nadmiernego forsowania inwestycji w gospodarce, pojawiły się cięcia w programie budowy autostrad. W ramach redukcji programu

4 J. Kaliński, Autostrady w Polsce, czyli drogi przez mękę, Łódź 2011, s. 11 i nast.

5 J. Kaliński, Historia polskich autostrad (2), „Autostrada” 1997, nr 11, s. 25; Decyzja z 21 stycznia 1969 r. o zatwierdzeniu studium budowy autostrady GOP - Kraków, w dokumentach Komisji Planowania przy Radzie Ministrów.

${ }_{6}$ Założenia wyjściowe do programu motoryzacji indywidualnej i budowy autostrad do $1990 \mathrm{r}$., w dokumentach Komisji Planowania przy Radzie Ministrów; Decyzja nr 28/72 Prezydium Rządu z 15 marca 1972 r. w sprawie prac przygotowawczych do budowy autostrad, w dokumentach Komisji Planowania przy Radzie Ministrów; Ustawa z dnia 24 maja 1989 r. o Funduszu Budowy Autostrad i Dróg Ekspresowych, Dz. U. 1989, nr 32, poz. 170. 
inwestycyjnego budowę południowej autostrady wschód - zachód ograniczono do odcinka Przylesie - Gliwice - Kraków?

Pod nadzorem powołanego w maju 1972 roku Zarządu Autostrad Krakowskie Biuro Projektów Dróg i Mostów przygotowało założenia techniczno-ekonomiczne odcinków Przylesie - Nogowczyce, Gliwice - Kraków oraz południowej obwodnicy Krakowa. Podczas tych prac pojawiły się pierwsze problemy na styku gospodarki, ochrony środowiska i dóbr kultury. Dla zespołu projektującego odcinek Gliwice Katowice istotna była analiza wpływu eksploatacji górniczej na trasę autostrady. Projektanci trasy Katowice - Kraków musieli uwzględnić postulaty dotyczące jej przebiegu przez Puszczę Dulowską i Garb Tenczyński oraz obok zespołu zabytkowego w Morawicy ${ }^{8}$.

Budowę odcinka Katowice - Kraków rozpoczęto w 1976 roku od Krakowa w stronę Chrzanowa, a w 1979 roku między Katowicami a Mysłowicami. Prace prowadziły: Krakowskie Przedsiębiorstwo Robót Drogowych, Kieleckie Przedsiębiorstwo Robót Mostowych, Energopol nr 2 z Krakowa i Przedsiębiorstwo Robót Inżynieryjnych z Tych. Do prac na odcinku Przylesie - Nogowczyce przystąpiono w 1977 roku. Postępy w budowie były mierne, a z początkiem lat 80. przerwano prace między Przylesiem a Nogowczycami oraz Katowicami a Mysłowicami. Powodem była dramatycznie pogarszająca się sytuacja gospodarcza kraju, uniemożliwiająca budżetowe finansowanie autostrad, a także brak odpowiedniego potencjału wykonawczego. Zlikwidowano także Zarząd Autostrad, a jego funkcje przejęły odpowiednie oddziały Generalnej Dyrekcji Dróg Publicznych (GDDP)

W konsekwencji efekty daleko odbiegały od zamierzeń, w styczniu 1983 roku oddano do ruchu odcinek Chrzanów - Balice, bez węzłów, długości $30 \mathrm{~km}$, a zakończenie budowy nastąiło w 1986 roku. Był to pierwszy odcinek autostrady A4 zbudowany w Polsce od podstaw. W 1986 roku zakończono także budowę 5,9-kilometrowego odcinka Byczyna - Chrzanów. W tym samym roku wznowiono budowę odcinka Przylesie - Nogowczyce, na którym po dwóch latach oddano do użytku jedną jezdnię na odcinku Przylesie - Prądy o długości $28 \mathrm{~km}$. Wolno przebiegały prace prowadzone przez Śląskie Przedsiębiorstwo Robót Drogowych między Byczyną a Mysłowicami, zakończone po 5 latach w 1991 roku. Od 1989 roku przy budowie drugiej jezdni oraz odcinka Prądy - Nogowczyce $(57 \mathrm{~km})$ pracowały: Śląskie Przedsiębiorstwo Robót Drogowych, Przedsiębiorstwo Robót Inżynieryjnych Przemysłu Węglowego w Katowicach, Przedsiębiorstwo Budownictwa Drogowego

7 A. Markowski, Drogownictwo w 1978 r., „Drogownictwo” 1978, nr 3, s. 65; Decyzja nr 77/76 Prezydium Rządu z dnia 23 stycznia 1976 r. w sprawie rozwoju transportu samochodowego oraz budowy dróg publicznych w latach 1976-1980, w dokumentach Komisji Planowania przy Radzie Ministrów.

8 Zarządzenie Ministra Komunikacji nr 77 z dnia 12 maja 1972 r. w sprawie powołania Zarządu Autostrad oraz określenia jego zadań i organizacji, DzMK 1972, nr 17, poz. 130; J. Kaliński, Historia polskich autostrad (4), „Autostrada” 1998, nr 1, s. 25.

9 J. Kaliński, Historia polskich autostrad (4), s. 25; A. Madeyski, Autostrada Kraków - Chrzanów, „Drogownictwo” 1984, nr 7, s. 175-177. 
i Mostowego we Wrocławiu, Rejon Budowy Mostów w Chrzanowie, Rejon Dróg Publicznych w Pszczynie, Kieleckie Przedsiębiorstwo Robót Mostowych i „Mostostal" Zabrze ${ }^{10}$.

Mimo niepowodzeń w budownictwie autostradowym, w tym szczególnie między Poznaniem a Warszawą, gdzie zamierzano uzyskać znaczny odcinek autostradowy przed olimpiadą 1980 roku w Moskwie, nie rezygnowano z planów długookresowych. W 1985 roku rząd przyjął Kierunkowy uktad sieci autostrad $i$ dróg ekspresowych, opracowany przy udziale specjalistów z ONZ ${ }^{11}$. Przewidywał on budowę 6 autostrad o długości ok. 1900 km: A1 - Gdańsk - Łódź - Katowice - granica z Czechosłowacją, A2 - Świecko - Poznań - Warszawa - Terespol, A3 - Szczecin - Zielona Góra - Legnica - granica z Czechosłowacją, A8 - Wrocław - Łódź i A18 - Olszyna na granicy z Niemcami - Krzyżowa. Jako A4 oznaczono południową autostradę równoleżnikową: Zgorzelec - Krzyżowa - Wrocław - Katowice - Kraków - Rzeszów - Przemyśl - Medyka. Kierunkowy układ przesądził dzisiejszy przebieg A4 od granicy zachodniej w Zgorzelcu do Krzyżowej i potwierdził przekroczenie granicy wschodniej w rejonie Przemyśla. W pierwszej kolejności przewidziano do realizacji odcinki autostradowe: Wrocław - Gliwice, Mysłowice - Byczyna i obwodnica Krakowa (Balice - Opatkowice).

Sumując, w ostatnim roku istnienia PRL w użytkowaniu było ogółem $210 \mathrm{~km}$ autostrad, z tego ponad połowę stanowiły odcinki dzisiejszej A4. Były to poniemiecka autostrada Krzyżowa - Wrocław $(99 \mathrm{~km})$ i zbudowane w Polsce Ludowej dwa odcinki między Katowicami a Krakowem (łącznie 36,7 km).

\section{PLANY I PRZYGOTOWANIA BUDOWY AUTOSTRADY A4 W TRZECIEJ RZECZYPOSPOLITEJ}

Zmiany ustrojowe, których konsekwencją było silne urynkowienie i internacjonalizacja polskiej gospodarki, zaowocowały przyspieszeniem prac koncepcyjnych nad autostradami. Motywowały je także sygnały płynące od władz Europejskiej Wspólnoty Gospodarczej (od 1993 roku Unii Europejskiej) o konieczności rozwoju i modernizacji połączeń komunikacyjnych Wspólnot Europejskich z Europą Środkową. Podczas Europejskiej Konferencji Ministrów Transportu na Krecie w 1994 roku ustalono przebieg dziewięciu transeuropejskich korytarzy transportowych (The Trans-European Networks - TENs), z których cztery przebiegały przez Polskę: Tallin - Warszawa, Berlin - Warszawa - Moskwa, Gdańsk - Katowice - Żylina i Berlin

10 J. Kaliński, Historia polskich autostrad (5), „Autostrada” 1998, nr 2, s. 24.

11 Commission of the European Communities, Trans-European Networks: Towards a Master Plan for The Road Network and Road Traffic, Brussels-Luxembourg 1992, s. 115; Postanowienie nr 55/85 Prezydium Rządu z 14 czerwca 1985 r. w sprawie kierunkowego układu autostrad i dróg ekspresowych oraz prac przygotowawczych do ich realizacji, w dokumentach Komisji Planowania przy Radzie Ministrów. 
- Kraków - Kijów. Ostatni z korytarzy nawiązywał do przebiegu planowanej autostrady A4. Pojawiły się także możliwości pomocy finansowej ze strony Unii oraz międzynarodowych instytucji finansowych dla realizacji programu modernizacji i rozbudowy sieci drogowej w Polsce ${ }^{12}$.

Przyjęty przez rząd w 1993 roku Program budowy autostrad w Polsce przewidywał stworzenie do 2007 roku sieci liczącej 2600 km autostrad. Dość szybko okazało się, że jest on nierealny, zarówno ze względów finansowych, jak i realizacyjnych, wobec czego wysunięto postulat skoncentrowania inwestycji na autostradzie A4. Wydane w 1996 roku rozporządzenie Rady Ministrów w sprawie ustalenia sieci autostrad i dróg ekspresowych uściśliło przebieg A4: (Drezno) Zgorzelec - Krzywa - Legnica - Wrocław - Opole - Katowice - Kraków - Tarnów - Rzeszów - Medyka (Lwów). Na jej trasie znajdować się miały węzły na skrzyżowaniu z A3 i A8 na Dolnym Śląsku oraz z A1 na terenie GOP. Autostrada miała połączyć dolnośląski okręg przemysłowo-rolniczy, opolski okręg intensywnej produkcji rolnej, GOP, krakowski region przemysłowo-turystyczny, tarnowski okręg przemysłowy i rzeszowski okręg przemysłowy ${ }^{13}$.

Zgodnie z Założeniami realizacyjnymi programu budowy autostrad na lata 1998-2015 w okresie 1998-2002 miały powstać odcinki Wrocław - Nogowczyce, Nogowczyce - Sośnica, Sośnica - Murckowska i Katowice - Kraków, między 2003 a 2010 rokiem - Zgorzelec - Wrocław, a w ostatnim okresie (2010-2015) zamierzano połączyć Kraków z Tarnowem ${ }^{14}$. Przyspieszenie i rozszerzenie realizacji programu autostradowego zapowiedział dokument rządu SLD-UP-PSL Infrastruktura - klucz do rozwoju z 2002 roku. Stworzony na jego podstawie Program budowy dróg krajowych $i$ autostrad na lata 2002-2005 zakładał zbudowanie ok. $550 \mathrm{~km}$ autostrad. Do połowy 2003 roku miała powstać obwodnica Krakowa, na następny rok przewidziano otwarcie odcinków Nogowczyce - Kleszczów - Sośnica - węzeł Wirek, w 2005 roku miał być gotowy odcinek Krzywa - Wrocław, a w 2006 Jędrzychowice - Krzyżowa. Do końca 2007 roku kierowcy mieli otrzymać ciąg autostradowy od granicy z Niemcami do Tarnowa ${ }^{15}$.

Pod wpływem narastających problemów z finansowaniem i realizacją autostrad w 2001 roku ograniczono jej docelową sieć do ok. $2000 \mathrm{~km}$, rezygnując z autostrady A3 i A8, którą ograniczono do zachodniej i północnej obwodnicy Wrocławia. W przygotowanej w 2003 roku przez Ministerstwo Infrastruktury strategii związanej

12 H. Chrostowska, Studia ekonomiczne budowy autostrad w Polsce, „Drogownictwo” 1992, nr 9, s. 193-196.

13 Ministerstwo Transportu i Gospodarki Morskiej, Program budowy autostrad w Polsce, Warszawa 1993, s. 3 i nast.; Rozporządzenie Rady Ministrów z 23 stycznia 1996 r. w sprawie ustalenie sieci autostrad i dróg ekspresowych, Dz.U. 1996, nr 12, poz. 63; Z. Jaworski, Program budowy autostrad w Polsce 1993-2007, „Drogownictwo” 1993, nr 9, s. 205-210.

14 E. Borecka-Smolińska, W pięć godzin od granicy do granicy, „Cash” 1994, nr 6, s. 16-17; S. Koziarski, Przeksztatcenia infrastruktury transportowej w Polsce, Opole 2010, s. 3-32; D. Słotwiński, D. Sybilski, Czy jesteśmy technicznie przygotowani do budowy autostrad, „Drogownictwo” 1994, nr 11, 251-258.

15 Ministerstwo Infrastruktury, Program budowy dróg krajowych i autostrad na lata 2002-2005, Warszawa 2002, s. 7. 
z rychłym przystąpieniem Polski do UE potwierdzono konieczność budowy A4. Jej podstawowy fragment od granicy niemieckiej do Tarnowa miał być gotowy w 2008 roku. W 2007 roku rząd zapowiedział, że w związku z przyznaniem Polsce i Ukrainie organizacji piłkarskich mistrzostw Europy Euro 2012 powstanie sieć ponad 1600 $\mathrm{km}$ autostrad. Oznaczało to konieczność wybudowania do maja 2012 roku $906 \mathrm{~km}$ nowych dróg samochodowych, w tym całej autostrady A4. Brakowało na niej odcinków: Jędrzychowice - Krzyżowa, Kleszczów - Murckowska, Kraków - granica państwa, o łącznej długości ok. $315 \mathrm{~km}^{16}$.

Od strony instytucjonalnej budownictwu autostradowemu służyć miało powołanie w 1995 roku Agencji Budowy i Eksploatacji Autostrad (ABiEA). Po nie najlepszych doświadczeniach z funkcjonowaniem Agencji 1 kwietnia 2002 roku, w miejsce zlikwidowanych GDDP i ABiEA, powołano Generalną Dyrekcję Dróg Krajowych i Autostrad (GDDKiA), odpowiedzialną za budowę i eksploatację autostrad państwowych. Natomiast podstawę realizacji programu autostradowego miały tworzyć krajowe i zagraniczne firmy prywatne, które stawały do przetargów organizowanych przez GDDKiA. Niepowodzeniem zakończyły się próby zlecenia budowy autostrad państwowym spółkom specjalnego przeznaczenia ${ }^{17}$.

Początkowo organizowano oddzielne przetargi na projektowanie i budowę dróg. Przed zbliżającymi się mistrzostwami Euro 2012, w celu przyspieszenia realizacji inwestycji, wprowadzono system „,projektuj i buduj”. Polegał on na zastąpieniu dwóch odrębnych przetargów na projektowanie i realizację inwestycji tylko jednym przetargiem na projekt i wykonanie. W kontrakcie wykonawca zobowiązywał się do wykonania projektu, a następnie jego realizacji.

Ambitny program autostradowy władz Trzeciej Rzeczypospolitej, w warunkach chronicznego deficytu budżetowego, napotkał problem jego sfinansowania. Preferowano budowę autostrad płatnych finansowanych z budżetu państwa, krajowych funduszy specjalnych, środków zagranicznych i prywatnych koncesjonariuszy ${ }^{18}$. W budowie autostrad przez państwo lub w ramach partnerstwa publiczno-prywatnego duże nadzieje wiązano z powołanym, dopiero na początku 2004 roku, w strukturze Banku Gospodarstwa Krajowego, Krajowym Funduszem Drogowym (KFD). Jego środki finansowe pochodziły głównie z opłaty paliwowej i opłat za przejazdy. W la-

16 Rozporządzenie Rady Ministrów z dnia 29 września 2001 roku w sprawie ustalenia sieci autostrad, dróg ekspresowych oraz dróg o znaczeniu obronnym, Dz.U. 2001, nr 120, poz. 1283; Strategia rozwoju infrastruktury transportu na lata 2004-2006 i dalsze, „Drogownictwo” 2003, nr 10, s. 311 i nast.; Program budowy dróg krajowych na lata 2008-2012, Załącznik do uchwały nr 163/2007 Rady Ministrów z dnia 25 września 2007 r.

17 Rozporządzenie Prezesa Rady Ministrów z dnia 13 maja 1995 r. w sprawie nadania statutu Agencji Budowy i Eksploatacji Autostrad, Dz.U. 1995, nr 52, poz. 283; M.K. Kozłowska, A. Oranowska, Drogowe spótki specjalnego przeznaczenia, „Przegląd Komunikacyjny” 2016, nr 8, s. 18-22; A. Serbreńska, Nowy rząd-nowy program drogowy, „Polskie Drogi” 2002, nr 3, s. 9.

18 Ustawa z 27 października 1994 r. o autostradach płatnych, Dz.U. 1994, nr 127, poz. 627; P. Świątecki, Ustawa o autostradach platnych, „Przegląd Komunikacyjny” 1995, nr 2, s. 1-4; Rozporządzenie Ministra Transportu i Gospodarki Morskiej z dnia 12 maja 1995 r. w sprawie szczegółowych zasad postępowania przetargowego na udzielenie koncesji na budowę i eksploatację autostrad płatnych, Dz.U. 1995, nr 58, poz. 306. 
tach 2005-2006 KFD finansował m.in. odcinki A4: Zgorzelec - Krzyżowa, Krzywa - Wrocław, Kleszczów - Sośnica i Sośnica - Murckowska ${ }^{19}$.

Od jesieni 1991 roku władze polskie skutecznie zabiegały w Banku Światowym (BŚ) o pożyczkę na modernizację zdewastowanego odcinka autostradowego na zachód od Wrocławia. W latach 1995-1996 dokonano modernizacji, a w zasadzie budowy od podstaw niewielkiego odcinka z Krzyżowej do Krzywej. Z Europejskiego Banku Odbudowy i Rozwoju (EBOR) finansowano odcinek Opole - Strzelce Opolskie i obwodnicę Krakowa oraz modernizowano miejski odcinek autostradowy w Katowicach i odcinek Katowice - Kraków. Środki z Europejskiego Banku Inwestycyjnego (EBI) i grantów funduszu Poland and Hungary: Assistance for Restructuring Their Economies (PHARE) szczególną rolę odegrały przy modernizacji i budowie odcinka Bielany Wrocławskie - Nogowczyce. Z grantu PHARE oraz pożyczki EBI budowano odcinek Nogowczyce - Sośnica - Katowice Murckowska oraz część obwodnicy Krakowa ${ }^{20}$.

Dość szybko pojawiły się środki z Unii Europejskiej. W 2000 roku, w związku z przygotowaniami do wejścia Polski do UE, uruchomiono Przedakcesyjny Instrument Polityki Strukturalnej (Instrument for Structural Policies for Pre-Accesion ISPA), którego zasady nawiązywały do działającego w UE Funduszu Spójności (Cohesion Funds - CF). Po wejściu naszego państwa do UE zakończył funkcjonowanie ISPA, a niedokończone projekty były realizowane ze środków CF. Ze środków ISPA i EBI przebudowywano i modernizowano odcinek autostradowy z Krzywej do Bielan Wrocławskich. $Z$ tego samego źródła oraz CF, EBI i PHARE budowano odcinki Jędrzychowice - Krzyżowa, Kleszczów - Chorzów Batory i fragmenty obwodnicy Krakowa. Po 2004 roku, wobec trudności z zaangażowaniem kapitału prywatnego, dominowały inwestycje finansowane przez budżet i KFD z poważnym udziałem środków unijnych w ramach $\mathrm{CF}$. W takiej formule budowano cały wschodni fragment autostrady od Krakowa do granicy z Ukrainą.

W ramach prac przygotowawczych do budowy autostrad niezmiernie ważny etap stanowiła procedura lokalizacyjna. Początkowo inicjatywa w tym zakresie należała do prezesa ABiEA, który zgodnie z ustawą o autostradach płatnych składał Ministrowi Spraw Wewnętrznych i Administracji (MSWiA) wniosek o udzielenie wskazań lokalizacyjnych. Pierwsze wnioski o wydanie wskazań lokalizacyjnych dla autostrad złożone zostały w 1994 roku. W sierpniu 1995 roku wydano odpowiednie dokumenty m.in. dla odcinków Wrocław - Opole - Gliwice i Katowice - Kraków. W połowie 1997 roku ABiEA dysponowała wskazaniami dla odcinków Zgorzelec - Wrocław, Gliwice - Katowice i Kraków - Tarnów. Pod koniec 1999 roku uzyskano wskazania dla odcinka Tarnów - Przeworsk. W tym samym roku nastąpiło ustalenie rządów

19 E. Talunas, Historia finansowania drogownictwa polskiego, „Drogownictwo” 2006, nr 2, s. 75; Ministerstwo Infrastruktury, Raport z realizacji Programu budowy dróg krajowych i autostrad, Warszawa 2004, s. 6; Program rzeczowo-finansowy dla inwestycji drogowych realizowanych z wykorzystaniem środków Krajowego Funduszu Drogowego na lata 2005-2006, „Biuletyn Informacyjny Drogownictwa” 2005, nr 1, s. 25; Realizacja programu budowy autostrad, „Polskie Drogi” 1996, nr 6, s. 3-5.

20 E.W. Archutowski, Drogi publiczne i ich finansowanie, „Drogownictwo” 2001, nr 11, s. 337 i nast. 
Polski i Ukrainy o poprowadzeniu autostrady A4 przez nowe przejście graniczne w Korczowej. Było to zwycięstwo strony ukraińskiej, gdyż władze ówczesnego województwa przemyskiego, zgodnie z lokalnym interesem gospodarczym, zabiegały o przejście graniczne w Medyce ${ }^{21}$.

Wraz z wytyczaniem autostrady pojawiły się nowe problemy środowiskowe. $\mathrm{Na}$ Śląsku ekolodzy sygnalizowali nadmierne zbliżenie zabudowy mieszkalnej do projektowanej drogi i potrzebę ochrony walorów przyrodniczych parku Kościuszki w Katowicach oraz Parku Kultury i Wypoczynku w Chorzowie. Kwestionowali także procedury przyjęte przy lokalizacji odcinka autostrady Opole - Gliwice. Zaktywizowały się spółki węglowe zainteresowane maksymalną ochroną pokładów węgla. Istotnym utrudnieniem dla inwestycji autostradowych na Śląsku były powszechnie obserwowane szkody górnicze. Tymczasem, zdaniem specjalistów drogowych, odstąpienie od przeprowadzenia autostrady A4 przez Gliwice, Zabrze, Chorzów i Katowice spowodowałoby, że 90-95\% ruchu odbywałoby się po sieci ogólnodostępnej w zabudowie miejskiej, przyczyniając się do pogorszenia warunków ekologicznych i komunikacyjnych aglomeracji górnośląskiej. W konsekwencji długo nie osiągano porozumienia dotyczącego lokalizacji odcinka autostrady między Gliwicami a Katowicami oraz skrzyżowania A4 z A1 w rejonie Gliwic ${ }^{22}$.

Do wykupu gruntów przystąpiono w 1996 roku na odcinkach Wrocław - Gliwice i Katowice - Kraków. Przewidywany koszt pozyskania nieruchomości dla odcinków Wrocław - Nogowczyce i Katowice - Kraków, wraz z obejściem południowym Krakowa, szacowano na $55 \mathrm{mln}$ zł. Wykup nieruchomości stwarzał wiele problemów i sytuacji konfliktowych, zwłaszcza w odniesieniu do proponowanych cen i ewentualnej zamiany gruntów. Niekiedy problemem stawała się nieobecność właściciela lub nieuporządkowane księgi wieczyste. Szczególnie trudne były przypadki, gdy budowę autostrady musiało poprzedzać rozebranie domów lub zabudowań inwentarskich ${ }^{23}$.

\section{PRÓBY REALIZACJI AUTOSTRADY W SYSTEMIE KONCESYJNYM}

Pierwszy przetarg na koncesję, odpowiadający warunkom ustawy o autostradach płatnych, ogłoszony został przez ABiEA dnia 19 czerwca 1995 roku. Agencja zaprosiła do udziału w kwalifikacji wstępnej dotyczącej udzielenia koncesji na przystosowanie do pobierania opłat oraz eksploatację istniejącego odcinka autostrady Kraków - Katowice. Specyfikację warunków kwalifikacji nabyło 11 firm, ale tylko 3 złożyły

${ }^{21}$ K. Grzegrzółka, Autostrady. W tym roku zacznie się wykupywanie gruntów, „Rzeczpospolita” 1996, 13.06, s. 2; S. Koziarski, Autostrady w Europie i w Polsce, „Przegląd Komunikacyjny” 1996, nr 7-8, s. 1621; M. Poniatowska-Jaksch, Autostrada a rozwój lokalny, Warszawa 1997, s. 23.

22 W. Suchorzewski, Program budowy autostrad a rozwój ekologicznie zrównoważony, „Drogownictwo" 1995, nr 5, s. 128; Stol, A-4 w Katowickiem, „Autostrada” 1998, nr 2, s. 6.

23 E. Dobrodziej, Realizacja Programu budowy autostrad, „Polskie Drogi” 1995, nr 11, s. 6; AS, Wykup gruntów pod autostrady, „Polskie Drogi” 2005, nr 10, s. XXVIII. 
wnioski. Były to konsorcja: Stalexport S.A., GTM Entrepose oraz Autostrada (Konsorcjum Drogowo-Mostowe) S.A. ${ }^{24}$

Komisja Przetargowa wybrała dnia 29 stycznia 1997 roku, jako przyszłego koncesjonariusza, Stalexport S.A. Grupa kapitałowa Stalexport S.A. liczyła 19 spółek krajowych oraz 8 stowarzyszonych, dysponujących kapitałem w wysokości $10 \mathrm{mln}$ $\mathrm{ECU}^{25}$. Umowę koncesyjną podpisano 19 września 1997 roku. W ramach koncesji, wydanej na 30 lat, Stalexport S.A. zobowiązała się do sfinansowania koniecznych prac modernizacyjnych ze środków własnych i kredytów, przystosowania autostrady do pobierania opłat, eksploatowania przez okres koncesji, a następnie przekazania państwu ${ }^{26}$.

Koncesjonariusz zobowiązany został do zorganizowania Placów Poboru Opłat (PPO), urządzenia miejsc obsługi podróżnych (MOP), zorganizowania służby autostradowej i przeprowadzenia telefonizacji, co wymagało początkowo $25 \mathrm{mln}$ USD nakładów inwestycyjnych. Do obowiązków spółki należała także poprawa stanu ochrony środowiska wzdłuż autostrady poprzez wybudowanie niezbędnych osłon przeciwhałasowych i przeciwolśnieniowych oraz zmodernizowanie systemu kanalizacji. Grupa Stalexport S.A. musiała także refundować budżetowi państwa spłatę 45 mln ECU pożyczki EBOR na budowę autostrady Kraków - Katowice. W celu realizacji zobowiązań przyjętych przez koncesjonariusza powołano w 1998 roku spółkę Stalexport Autostrada Małopolska S.A. (SAM S.A.). Eksploatację autostrady powierzono spółce Stalexport - Transroute Autostrada S.A., należącej do grupy kapitałowej Stalexport - Autostrady S.A. Do jej zadań należała eksploatacja systemu poboru opłat, zarządzanie ruchem na autostradzie, utrzymywanie wyposażenia autostrady w odpowiednim stanie technicznym, pełne utrzymanie całości obszaru autostrady, utrzymanie zimowe autostrady i doradztwo w sprawach przyszłych remontów i napraw nawierzchni oraz projektów podniesienia standardu drogi.

$\mathrm{Na}$ koncesjonowanym odcinku A4 Katowice - Kraków od 2006 roku ożywiły się prace modernizacyjne. Umożliwiły to kredyty bankowe SAM S.A. w wysokości $380 \mathrm{mln}$ zł, na podstawie umowy z konsorcjum banków: Westdeutsche Landesbank, DePfa Group, Creditanstalt fur Wiederaufbau i BPH S.A. Między 2003 a 2007 rokiem Przedsiębiorstwo Robót Inżynieryjnych S.A. Holding wyremontowało 16 mostów, naprawiło $27 \mathrm{~km}$ podwójnej jezdni, wykonało 15 przejazdów awaryjnych i postawiło $6,6 \mathrm{~km}$ wysokich ekranów akustycznych. Jednak wiele wiaduktów, mających 30-40 lat, było w złym stanie technicznym i zagrażało bezpieczeństwu ruchu. Dlatego w marcu 2008 roku firma SAM S.A. zawarła kontrakt ze spółką Pavimental S.p.A. na remont 10 obiektów mostowych, remont nawierzchni na pasach ruchu i pasach awaryjnych na długości około $26 \mathrm{~km}$, remont nawierzchni bitumicznej dwóch PPO oraz remont łącznic dwóch węzłów autostradowych. Wartość kontraktu wyniosła 142,2 mln zł. Do końca 2009 roku zmodernizowano nawierzchnię na całym odcinku oraz wszystkie obiekty mostowe w ciągu autostrady. Na podstawie tej umowy

24 Przetargi na budowę autostrad, „Polskie Drogi” 1996, nr 2, s. 6.

25 ECU - waluta rozliczeniowa EWG i UE przed wprowadzeniem EUR.

26 A. Jarucka, Pierwsze koncesje, „Autostrada” 1997, nr 2, s. 6; Pierwsza koncesja dla Stalexportu, „Rzeczpospolita” 1997, 30 stycznia, s. 1. 
spółka SAM S.A. zrealizowała i zakończyła w październiku 2009 roku kolejny etap przedsięwzięcia, tj. gruntowny remont nawierzchni, modernizację części obiektów mostowych, budowę przejazdów awaryjnych i ekranów akustycznych. W następnych latach kontynuowano modernizację mostów i rozbudowę PPO oraz przebudowę niektórych węzłów ${ }^{27}$.

Przetarg, ogłoszony przez ABiEA dnia 23 czerwca 1997 roku, dotyczył koncesji na budowę i eksploatację odcinka Wrocław - Katowice $(187 \mathrm{~km})$. Chodziło o przystosowanie do pobierania opłat budowanej przez państwo autostrady na odcinkach Bielany Wrocławskie - Nogowczyce i Sośnica - Chorzów Batory, wybudowanie i wprowadzenie systemu pobierania opłat na odcinku Nogowczyce - Sośnica oraz eksploatację odcinka Wrocław - Katowice z utrzymaniem bezpłatnego odcinka Chorzów Batory - węzeł Murckowska. Do 10 grudnia dokumentację złożyły firmy: Pekaes Auto-Transport S.A. w Warszawie, Opolskie Konsorcjum Budowy Autostrad S.A. w Opolu i Stalexport Autostrada Śląska S.A. (SAŚ S.A.).

Przetarg koncesyjny przerwano w 1999 roku, co spotkało się z krytyczną oceną Najwyższej Izby Kontroli (NIK). Po jego wznowieniu przeprowadzono tylko pierwszy etap. Do drugiego etapu (ofertowego), który nie został rozstrzygnięty, zakwalifikowano spółki: SAŚ S.A., Autostrada Południowa S.A. (AP S.A.) i Buygues-Polska S.A. Powodem ponownego wstrzymania przetargu w 2001 roku była zmiana strategii autostradowej, odejście od systemu koncesyjnego na rzecz opłat winietowych. Według GDDKiA brak opłat na autostradzie Wrocław - Katowice powodował utratę potencjalnych przychodów brutto w wysokości ok. 120-150 mln rocznie. Dodatkowo autostrada, mimo wybudowania 16 MOP-ów i PPO, nie uzyskała pełnej infrastruktury, a niektóre jej elementy podlegały dekapitalizacji, co obniżało poziom bezpieczeństwa jazdy ${ }^{28}$. Nie ogłoszono, przewidywanego na drugą połowę 1997 roku, przetargu na koncesję dla odcinka autostrady A4 granica z Niemcami - Wrocław.

Problemy związane $\mathrm{z}$ wdrażaniem systemu koncesyjnego sprawiły, że jego efekty odsuwały się w czasie. Wystąpiły także problemy ze sprawnym funkcjonowaniem sprywatyzowanych odcinków. Stalexport S.A. przeprowadził ocenę przejętych obiektów, która wykazała, że $80 \%$ mostów wymaga remontów. Mimo że stan techniczny autostrady daleko odbiegał od norm bezpieczeństwa i trwały prace remontowe, od 2000 roku pobierano opłaty w ramach tzw. rozruchu technologicznego na odcinkach Mysłowice - Byczyna, Byczyna - Chrzanów i Chrzanów - Balice. Wpływy z tego tytułu wyniosły: 46,4 mln zł w 2000 roku, 73,3 mln zł w 2001 roku i 76,7 mln zł w 2002 roku. W dokumentach pokontrolnych NIK z 2003 roku znalazła się krytyka pobierania opłat za przejazdy po autostradzie A4 Katowice - Kraków, ponieważ umowa koncesyjna na eksploatację tego odcinka nie przewidywała i nie definiowała pojęcia „rozruch technologiczny autostrady”. Przeciągające się remonty, zdaniem NIK, sprawiały, że droga nie spełniała wymogów autostrady płatnej i pobieranie opłaty za przejazd było nielegalne ${ }^{29}$.

27 Stalexport Autostrada Małopolska S.A. - koncesjonariusz platnego odcinka autostrady A4 Katowice - Kraków, http://sam.autostrada-a4.com.pl/o_firmie/historia_stalexport [dostęp: 10.04.2015].

${ }^{28}$ J. Kaliński, Autostrady w Polsce..., s. 56-57.

29 NIK, Informacja o wynikach kontroli budowy autostrad w Polsce, Warszawa 2003, s. 47 i nast. 
Po powstaniu w 2005 roku rządu PiS, sceptycznie nastawionego do roli kapitału prywatnego $\mathrm{w}$ realizacji programu autostradowego, unieważniono postępowanie przetargowe na pobór opłat na odcinku Wrocław - Katowice, w którym uczestniczyły AP S.A. i SAŚ S.A. Pojawiła się także próba odebrania SAM S.A. koncesji na eksploatację odcinka Katowice - Kraków. Świadczyło to o klęsce, zainaugurowanego w połowie lat 90., programu budowy autostrad płatnych w systemie koncesyjnym. Dowodziło nie tylko braku zaangażowania kapitału prywatnego, ale także niedostatecznych działań ze strony władz i administracji drogowej.

\section{BUDOWA AUTOSTRADY W SYSTEMIE TRADYCYJNYM}

W Trzeciej Rzeczypospolitej w 1992 roku, na podstawie umowy między Polską a Niemcami, podjęto budowę granicznego połączenia autostradowego w rejonie Zgorzelca $^{30}$. Od 1994 roku włoska firma Italsagi z polskim podwykonawcą Przedsiębiorstwem Robót Inżynieryjnych w Katowicach budowały odcinek między Katowicami a Mysłowicami. Jednak jako pierwszy krok w realizacji programu budowy autostrad w Trzeciej Rzeczypospolitej i przyspieszeniu inwestycji na A4 uznaje się początek maja 1997 roku, kiedy premier Włodzimierz Cimoszewicz, w towarzystwie ministra transportu Bogusława Liberadzkiego, komisarza Komisji Europejskiej do spraw Transportu Neila Kinnocka, wiceprezydenta EBI Wolfganga Rotha, ambasadora Unii Europejskiej w Polsce Rolfa Timansa i prezesa ABiEA Andrzeja Patalasa, wmurował w okolicach Krapkowic kamień węgielny pod przebudowę i modernizację odcinka Bielany Wrocławskie - Nogowczyce. Realizacja odcinka długości $126 \mathrm{~km}$, przy której wykorzystano fragmenty autostrady poniemieckiej, była największym przedsięwzięciem autostradowym lat 90 . Jego skala zdecydowanie przerastała możliwości polskich firm budowlanych, które w przetargach musiały stawiać czoła renomowanym firmom zagranicznym. Szansą dla polskich wykonawców stała się współpraca typu joint venture (j.v.). Utworzona w tej formie spółka Deutsche Asphalt $\mathrm{GmbH}$ i Dromex S.A. podpisała dwa kontrakty na realizację odcinków Bielany Wrocławskie - Przylesie i Przylesie - Prądy. Obiekty mostowe na odcinku Bielany Wrocławskie - Prądy budowała firma portugalska Mota\&Companhia S.A., zaś odcinki autostradowe Prądy - Dąbrówka i Dąbrówka - Nogowczyce - j.v. Ilbau Polska i Hermann Kirchner. Budowę zachodniego odcinka A4 hamowały incydenty z ekologami. W 1998 roku wystąpiły one w związku z przejściem autostrady w rejonie Góry Świętej Anny i lasów niemodlińskich. Przez pięć tygodni trwały utrudnienia

30 Umowa między Rzecząpospolitą Polską a Republiką Federalną Niemiec o połączeniu autostrad oraz budowie urządzeń odprawy granicznej dla nowego przejścia granicznego w rejonie Zgorzelca i Gorlitz sporządzona w Warszawie dnia 29 lipca 1992 r., Dz.U. 1994, nr 74, poz. 333. 
na placu budowy spowodowane przez protestujących. Dodatkowo plany drogowców pokrzyżowała wielka powódź na Dolnym Śląsku latem 1997 roku $^{31}$.

W latach 2002-2004 podpisano kontrakty na wykonanie przebudowy autostrady A4 między Krzywą a Wrocławiem. Budowę południowej jezdni z Krzywej do Wądroża Wielkiego oraz jezdni północnej odcinka Krzywa - Legnica wykonać miały firmy Strabag AG, Strabag AG Germany i Mota\&Companhia S.A.; prace na odcinku Wądroże Wielkie - Bielany Wrocławskie, jezdnię południową i obiekty inżynierskie - j.v. Walter+Heilit Verkehrswegebau/Budimex Dromex S.A., zaś jezdnię północną odcinka Legnica - Bielany Wrocławskie - konsorcjum Hermann Kirchner, Max Bögl, Berger Bau ${ }^{32}$.

Od 2002 roku prowadzono prace na odcinku A4 Sośnica - Wirek - Chorzów Batory. Z Sośnicy do węzła Wirek wykonawcą była spółka niemiecko-austriacka Strabag i Hermann Kirchner, zaś od węzła Wirek j.v. polskich firm GPRD, WPRD i PRInż. S.A. Holding. Drogowcy spotkali się tu z bardzo trudnymi warunkami terenowymi, których przyczyną były szkody górnicze. Podbudowę autostrady wykonywano według standardów stosowanych na terenach oddziaływania sejsmicznego. Niezbędne były dodatkowe prace i wzmocnienia, pojawiła się konieczność naprawy nasypu. Powstał spór między Kompanią Węglową a drogowcami domagającymi się odszkodowań. W 2003 roku budowę odcinka Kleszczów - Sośnica podjęły firmy MSF - Moniz da Maia, Serra \& Fortunato - Empreiteiros S.A. i Teodoro Gomes Alho \& Filhos, LDA ${ }^{33}$.

Śląskie Przedsiębiorstwo Robót Mostowych, Szczecińskie Przedsiębiorstwo Budownictwa Przemysłowego, włoska firma Italsagi-Sallini-Girola i Przedsiębiorstwo Robót Inżynieryjnych w Katowicach remontowały odcinek z Katowic do Mysłowic. Podobne prace wykonywały Teerbau GmbH z Niemiec, Dromex S.A., „Mosty” Chrzanów, „Mostar” Sosnowiec, Przedsiębiorstwo Robót Kolejowych nr 5 i Kieleckie Przedsiębiorstwo Robót Mostowych na znacznie dłuższym odcinku Mysłowice - Kraków. Obejmowały one mosty i nawierzchnię w celu podniesienia jej nośności do 11,5 tony na oś. Realizowano także część obwodnicy południowej Krakowa od Balic w kierunku Opatkowic do połączenia z drogą do Zakopanego. Na jesieni 1999 roku podpisano kontrakt zj.v. polskich firm Dromex S.A. i Przedsiębiorstwo Robót Inżynieryjnych S.A. Holding na budowę fragmentu obwodnicy Krakowa od ul. Kąpielowej do potoku Malinówka długości 5,8 km. Umowę na kolejny odcinek od potoku Malinówka do węzła Wielicka $(2 \mathrm{~km})$ podpisano we wrześniu 2000 roku z j.v. Gdańskiego Przedsiębiorstwa Robót Drogowych i Kieleckiego Przedsiębiorstwa Robót Mostowych (w 2003 roku przekształcone w GPRD Skanska S.A. i KPRM Skanska S.A.).

31 K. Badora, Autostrada - środowisko przyrodnicze. Studium konfliktów przestrzennych na przykładzie opolskiego odcinka autostrady A-4, Opole 2004, s. 117 i nast.; R. Kostuch, Góra Świętej Anny i autostrada, „Aura” 1996, nr 7, s. 16-18.

32 Archiwum GDDKiA 2002-2004, www.gddkia.gov.pl [dostęp: 20.09.2016].

33 Budowa autostrady A4 na terenie oddziatu Katowice, „Magazyn Autostradowy” 2003, nr 6, s. 81-83; JR, Autostrada nad kopalniami, „Polskie Drogi” 2003, nr 12, s. 34-35. 
W październiku 2006 roku podpisano umowę na przebudowę odcinka Balice Opatkowice z dostosowaniem do nośności 11,5 tony na oś, za $150 \mathrm{mln}$ zł. Wykonawcą robót, które rozpoczęły się w kwietniu następnego roku, było konsorcjum firm Mota-Engil Polska S.A. i Mota-Engil, Engenharia e Construcao S.A. W listopadzie zawarto kontrakty na budowę odcinka Jędrzychowice - Krzyżowa, dla odcinka Jędrzychowice - Wykroty z DTP Terrassement S.A. i Bouygues Travaux Publics z Francji oraz VSL S.A. ze Szwajcarii, a dla odcinka Wykroty - Krzyżowa z j.v. firm Strabag Sp. z o.o., Strabag AG, Heilit+Woerner Bau GmbH, Mota-Engil i Engenharia e Construcao S.A.

Na początku kwietnia 2007 roku sfinalizowano umowę na budowę, kosztem 839,3 mln zł, odcinka Kraków - Szarów. W niespełna miesiąc później do budowy przystąpiło konsorcjum polsko-hiszpańskie Dragados S.A. i Polimex-Mostostal S.A., inaugurując inwestycje autostradowe związane z Euro 2012. W maju 2008 roku zawarto umowę ze spółką J\&P-Avax Polska S.A. na budowę wielopoziomowego węzła Gliwice - Sośnica na skrzyżowaniu autostrad A4 i A1 ${ }^{34}$.

Koszt budowanej przez państwo autostrady A4, poza górnośląskimi odcinkami Sośnica - Wirek (9,7 mln euro za $1 \mathrm{~km})$ i Wirek - Chorzów Batory (12,7 mln euro), był zdecydowanie niższy od odcinków koncesjonowanych. W przypadku odcinka A1 Nowe Marzy - Czerniewice koszt $1 \mathrm{~km}$ kształtował się na poziomie 11,7 mln euro, zaś jeśli chodzi o A2 Świecko - Nowy Tomyśl, było to aż 15,2 mln euro. Tymczasem koszt $1 \mathrm{~km}$ autostrady A4 Jędrzychowice - Krzyżowa wyniósł 6,1 mln euro, a odcinka Nogowczyce - Kleszczów - 3,9 mln euro ${ }^{35}$.

Pod koniec października 2009 roku rozstrzygnięto przetarg na budowę odcinka Szarów - Brzesko. Uczestniczyło w nim siedem firm i konsorcjów. Najniższą cenę zaproponowało polsko-słowacko-czeskie konsorcjum firm Polimex-Mostostal S.A., Doprastav AS i Metrostav as. Cena, na poziomie $779 \mathrm{mln}$ zł, okazała się o blisko połowę niższa od przyjętej w kosztorysie inwestorskim. Na początku listopada w rzeszowskim oddziale GDDKiA została podpisana umowa na budowę odcinka autostrady Jarosław - Korczowa (granica państwa). Fragment z Jarosławia do Radymna miał wybudować Budimex-Dromex S.A. i hiszpański Ferrovial Agroman za $970 \mathrm{mln}$ zł, a z Radymna do Korczowej grecka firma J\&P Avax za $820 \mathrm{mln}$ zł. Przyjęty kosztorys okazał się o $650 \mathrm{mln}$ zł niższy od przygotowanego przez GDDKiA.

Pod koniec listopada 2009 roku w krakowskim oddziale GDDKiA rozstrzygnięto przetarg na budowę 21-kilometrowego odcinka autostrady A4 Brzesko - Tarnów Zachód (Wierzchosławice). Zwyciężyło polsko-macedońskie konsorcjum firm NDI S.A. z Warszawy oraz SB Granit S.A. ze Skopie, które złożyło ofertę w wysokości $622,5 \mathrm{mln}$ zł. Zaproponowana suma była o połowę niższa od ujętej w kosztorysie inwestorskim. Dwóch spośród pozostałych uczestników przetargu oprotestowało rozstrzygnięcie. Sprawa trafiła do Krajowej Izby Odwoławczej, która orzekła, że stanowisko komisji przetargowej było słuszne. Podpisanie umowy nastąpiło na początku lutego 2010 roku.

\footnotetext{
34 Archiwum GDDKiA 2006, 2007, www.gddkia.gov.pl [dostęp: 20.09.2016].

35 J. Kaliński, Autostrady w Polsce..., s. 69.
} 
Według GDDKiA w 2009 roku średnia cena uzyskana w przetargach była o 27\% niższa od zakładanej w kosztorysach, co dało 8 mld zł oszczędności. Niższe ceny kontraktów miały ścisły związek z nasilającym się światowym kryzysem finansowym. Skłaniał on firmy drogowe do weryfikacji kosztorysów w kierunku zwiększenia konkurencyjności na rynku budowlanym. Nowa sytuacja niespodziewanie stała się pozytywnym czynnikiem realizacji programu autostradowego. W rezultacie koszt $1 \mathrm{~km}$ autostrady na wschodnim fragmencie A4 wahał się w przedziale 7-10 mln euro $^{36}$.

W styczniu 2010 roku, w przetargu na odcinek Rzeszów Zachód - Rzeszów Północ, składający się z 4-kilometrowego odcinka autostrady A4 i drogi ekspresowej $\mathrm{S} 19$, wybrano ofertę złożoną przez konsorcjum firm z liderem - firmą Radko Sp. z o.o. oraz partnerami Autostrada Wschodnia Sp. z o.o. z Warszawy i Punj Lloyd Ltd z Indii. Budowa tego odcinka miała kosztować ponad $442 \mathrm{mln}$ zł. W tym samym miesiącu rozstrzygnięto przetarg na odcinek Tarnów Zachód - Tarnów Krzyż długości $13 \mathrm{~km}$. Kontrakt wartości 542,8 mln zł uzyskała hiszpańska firma Dragados S.A., która zobowiązała się wybudować autostradę w ciągu dwóch lat. Pod koniec lutego w rzeszowskim oddziale GDDKiA podpisano umowę na budowę odcinka od węzła Rzeszów Północ do węzła Rzeszów Wschód długości 6,9km. Kontrakt wartości 439,5 mln zł, zdecydowanie niższy, niż zakładał kosztorys inwestora, uzyskało polsko-hiszpańskie konsorcjum firm Mostostal Warszawa S.A. i Acciona Infraestructuras.

Umowę na budowę 33-kilometrowego odcinka od węzła Dębica Pustynia do węzła Rzeszów Zachód podpisano 10 maja 2010 roku. Kontrakt, o wartości 1,73 mld zł, uzyskała firma Budimex S.A., która zobowiązała się do ukończenia inwestycji w czerwcu 2012 roku. Na początku lipca nastąpiło podpisanie umowy na budowę 35-kilometrowego odcinka autostrady A4 od węzła Tarnów Krzyż do węzła Dębica Pustynia. Przetarg wygrało irlandzko-polskie konsorcjum firm SIAC Construction Ltd, PBG S.A., APRIVIA S.A. i Hydrobudowa Polska S.A. Wartość kontraktu wyniosła $1,75 \mathrm{mld}$ zł, a jego zakończenie ustalono na czerwiec 2012 roku. Umowę na ostatni, 41-kilometrowy, odcinek autostrady A4 Rzeszów Wschód - Jarosław podpisano 23 września 2010 roku. Wyłonionym w drodze przetargu wykonawcą było konsorcjum Polimex Mostostal S.A. i Doprastav a.s. (Słowacja), wartość inwestycji wynosiła 2,2 mld $\mathrm{zt}^{37}$.

Łącznie do 2010 roku podpisano umowy z wykonawcami ostatniego zachodniego odcinka Jędrzychowice - Krzyżowa i wszystkich odcinków wschodniej części autostrady Kraków - Korczowa. Z pewnością był to największy w historii polskich autostrad przyrost decyzji inwestycyjnych, który budził optymizm co do możliwości szybkiego stworzenia w naszym kraju sieci nowoczesnych dróg samochodowych. Dodatkowo niższe od kosztorysu inwestora były oferty wykonawców na odcinkach Szarów - Brzesko, Brzesko - Tarnów Zachód, Rzeszów Północ - Rzeszów Wschód i Jarosław - Korczowa. Znaczne różnice między kosztorysami inwestora

\footnotetext{
36 Archiwum GDDKiA 2009, 2010, www.gddkia.gov.pl [dostęp: 20.09.2016].

37 Ibidem.
} 
a wykonawców, zauważane przez specjalistów, nie budziły refleksji po stronie władz drogowych. Tymczasem ich skutki finansowe, początkowo korzystne, wkrótce negatywnie zaważyły na realizacji programu autostradowego. Inwestycje oparte na nierealnych cenach ulegały opóźnieniu. Pogłębiły je problemy związane z wykonawstwem, środowiskowe i o charakterze losowym (powodzie) ${ }^{38}$.

Na koniec 2010 roku zaawansowanie odcinka Rzeszów - Korczowa oceniano na 6\%, Tarnów - Rzeszów na 7\%, a Szarów - Tarnów na 10\%. Opóźnienia w budowie oznaczały dotkliwą klęskę projektu uzyskania przed Euro 2012 ciągu autostradowego od granicy niemieckiej do ukraińskiej. Władze drogowe zmuszone zostały nie tylko do przesunięcia terminu zakończenia budowy autostrady na wschód od Krakowa, ale także do zmiany jej niektórych wykonawców i dodatkowego finansowania.

W lutym 2011 roku nastąpiło wypowiedzenie przez GDDKiA umowy z konsorcjum NDI S.A. - SB Granit S.A. na budowę odcinka węzeł Brzesko - węzeł Tarnów Zachód. Według Generalnej Dyrekcji winę za rozwiązanie umowy ponosił wykonawca, który dopuścił do wielomiesięcznego opóźnienia w realizacji kontraktu i nie płacił podwykonawcom. Podnoszono także kwestie nielegalnego zatrudniania macedońskich pracowników. Wykonawca z kolei przerzucał odpowiedzialność na GDDKiA, która jakoby nie uwzględniła postulatów finansowych związanych ze wzrostem kosztów budowy, wywołanych stratami powodziowymi. W kwietniu konsorcjum porzuciło budowę. Dyrekcja przewidywała, że wykorzystując niektóre przepisy ustawy o zamówieniach publicznych, uda się wprowadzić jesienią 2011 roku nowego wykonawcę. Wykonawcą porzuconego odcinka zostało wybrane w drodze przetargu konsorcjum Heilit+Woerner Budowlana, Strabag, Poldim i Przedsiębiorstwo Inżynieryjne IMB - Podbeskidzie. Konsorcjum za $642 \mathrm{mln}$ zł zobowiązało się dokończyć prace na autostradzie do października 2012 roku. Pojawiły się jednak nowe problemy, spowodowane upadłością uczestnika konsorcjum - firmy Poldim. Dodatkowo niewypłacone przez nią kwoty należne podwykonawcom były powodem protestów i blokowania dróg ${ }^{39}$.

Pod koniec maja 2012 roku GDDKiA zdecydowała o odstąpieniu od umowy na budowę odcinka Rzeszów Zachód - Rzeszów Północ, gdyż dotychczasowy wykonawca, polsko-indyjskie konsorcjum Radko Sp. z o.o., Autostrada Wschodnia Sp. z o.o. i Punj Lloyd Ltd, wykazywał brak płynności finansowej. Tymczasem w przyjętym w kontrakcie terminie zrealizowano tylko $49 \%$ prac. W rozstrzygniętym w połowie października 2012 roku nowym przetargu najniższą ofertę w wysokości $184 \mathrm{mln}$ zł brutto przedstawił Budimex S.A. Firma zobowiązała się do wykonania w ciągu 14 miesięcy części nasypów i warstw konstrukcyjnych nawierzchni oraz dokończenia prac budowlanych przy węźle Rzeszów Zachód i Obwodzie Utrzymania Autostrady (OUA), a także niezbędnych prac wykończeniowych.

Gdy zbliżał się planowy termin oddania do użytku odcinka od Radymna do przejścia granicznego w Korczowej, zaawansowanie budowy oceniano na $50 \%$.

38 A. Stefańska, Poczekamy na autostrady, ,Rzeczpospolita. Ekonomia \& Rynek” 2012, 28 czerwca, s. B1.

39 Archiwum GDDKiA 2011, www.gddkia.gov.pl [dostęp: 20.09.2016]. 
Niezbędne było wprowadzenie aneksu do umowy z grecką firmą J\&P Avax, przedłużającego budowę o ponad rok. Tymczasem powodzie były powodem opóźnień na budowie odcinka z Szarowa do Tarnowa.

W lipcu 2012 roku konsorcjum firm SIAC Construction Ltd, PBG S.A., APRIVIA S.A. i Hydrobudowa Polska S.A., które nie wywiązywało się z zapisów kontraktowych, przestało realizować budowę odcinka Tarnów Krzyż - Dębica Pustynia, zażądało dopłaty $200 \mathrm{mln}$ zł, a następnie odstąpiło od umowy przy 50-procentowym zaawansowaniu kontraktu. Konsorcjum zarzuciło GDDKiA nierzetelne zarządzanie projektem i niewywiązywanie się z zobowiązań. Doprowadziło to do zerwania umowy przez Generalną Dyrekcję i podjęcia procedury wyboru nowego wykonawcy. Pod koniec listopada ogłoszono przetarg na dokończenie przerwanej budowy, który w marcu 2013 roku wygrało konsorcjum firm Heilit Woerner Sp. z o.o. i Budimex S.A.W ciągu 18 miesięcy, za kwotę $981 \mathrm{mln}$ zł, konsorcjum miało dokończyć budowę $35 \mathrm{~km}$ odcinka dwujezdniowej autostrady, węzłów Dębica Żyraków i Dębica Pustynia, dwóch MOP-ów, jednego Obwodu Utrzymania Autostrady oraz szeregu obiektów inżynierskich. W połowie 2014 roku zaawansowanie tego odcinka autostrady wynosiło $75 \%$, co dawało podstawę do twierdzenia, że w październiku zostanie uzyskana jego przejezdnośćc ${ }^{40}$.

W połowie 2012 roku najmniej zaawansowany (38\%) był odcinek Rzeszów Wschód - Jarosław Zachód. Jednym z powodów były problemy ekologiczne związane z siedliskami żab. Jednak dopiero na początku 2014 roku GDDKiA zdecydowała się na zerwanie kontraktu z konsorcjum Polimex Mostostal S.A. i Doprastav a.s. (Słowacja). Jako przyczyny podano niewypłacalność, niewywiązywanie się konsorcjum z zapisów kontraktowych oraz duże opóźnienia w realizacji kontraktu. W chwili odstąpienia od umowy zaawansowanie rzeczowe wynosiło $69 \%$, natomiast upływ czasu $105 \%$. Niewypłacalność konsorcjum spowodowała konieczność wypłaty przez GDDKiA odszkodowania w wysokości $325 \mathrm{mln}$ zł, głównie dostawcom towarów i usług. W przetargu na kontynuowanie budowy odcinka Rzeszów Wschód - Jarosław Zachód najkorzystniejszą ofertę złożyło konsorcjum firm Budimex S.A. i Strabag Sp. z o.o., które zobowiązało się do zrealizowania projektu w ciągu 14 miesięcy za $719 \mathrm{mln} \mathrm{z}^{41}$.

\section{EFEKTY}

Pierwszymi odcinkami autostradowymi oddanymi do użytku po 1989 roku były przekazane do ruchu w 1991 roku odcinki Mysłowice - Byczyna $(18,7 \mathrm{~km})$ i Balice - węzeł Tyniec $(7,4 \mathrm{~km})$ oraz ukończony w 1993 roku następny fragment obwodnicy

40 Archiwum GDDKiA 2012, www.gddkia.gov.pl [dostęp: 15.05.2015].

41 Archiwum GDDKiA 2014, www.gddkia.gov.pl [dostęp: 15.05.2015]; M. Bujara, Poślizg na autostradzie. Wszystkiemu winne żaby, Gazeta.Pl, 14.02.2011. http://rzeszow.wyborcza.pl/rzeszow /1,34962,9106519,Poslizg_na_autostradzie_Wszystkiemu_winne_zaby.html [dostęp: 15.05.2015]. 
Krakowa - węzeł Tyniec - Sidzina (4 km), który dopiero w 2002 roku został oznakowany jako autostrada. Obie inwestycje podjęto w drugiej połowie lat 80. W 1994 roku, po trzech latach budowy, przekazano niewielki odcinek na zachodzie - granica państwa - Jędrzychowice (1,8 km), a w 1995 roku kierowcy mogli skorzystać z kolejnych fragmentów autostrady pod Krakowem - Sidzina - węzeł Zakopiański (4,7 $\mathrm{km})$ i Opatkowice - ulica Kąpielowa $(0,7 \mathrm{~km})$. W 1996 roku zakończono, trwającą od 1989 roku, budowę, liczącego 6,3 km, odcinka Katowice Murckowska - Mysłowice. W tym samym roku sfinalizowano remont odcinka Krzyżowa - Krzywa $(10 \mathrm{~km})$, a w następnym zmodernizowano 38-kilometrowy odcinek między Legnicą a Wrocławiem i otwarto, jak wówczas podkreślano, „,bardzo sprawnie zmodernizowany" odcinek Katowice - Kraków. Jednak szybko okazało się, że koncesjonowana autostrada nadal daleko odbiegała od standardów jakościowych i wymagała dalszych prac remontowych. W 1999 roku udostępniono do ruchu odcinek w Katowicach między węzłem Mikołowska a węzłem Murckowska $(3,9 \mathrm{~km})^{42}$.

Przed końcem 2000 roku przekazano do eksploatacji liczący 90,7 km ciąg Bielany Wrocławskie - Dąbrówka, na który składały się: przebudowany odcinek Bielany Wrocławskie - Przylesie (40,6 km) oraz nowe odcinki Przylesie - Prądy $(28,7 \mathrm{~km})$ i Prądy - Dąbrówka (21,4 km). Jego przedłużenie o 34,4 km nastąpiło wraz z ukończeniem w lipcu 2001 roku odcinka Dąbrówka - Nogowczyce. W listopadzie oddano do ruchu odcinek Chorzów Batory - węzeł Mikołowska w Katowicach, długości 4,4 km. W grudniu 2002 roku otwarto dla ruchu 5,9-kilometrowy odcinek obwodnicy Krakowa od ulicy Kąpielowej do potoku Malinówka, a we wrześniu 2003 roku włączono do ruchu odcinek potok Malinówka - węzeł Wielicka $(1,1 \mathrm{~km})$. Pod koniec roku dokonano otwarcia, liczącego 17,9 km, odcinka Nogowczyce - Kleszczów, poprowadzonego w znacznej części po śladzie autostrady poniemieckiej ${ }^{43}$.

Do 2004 roku w korytarzu A4 skoncentrowane były krajowe inwestycje autostradowe realizowane w systemie tradycyjnym. Łącznie zbudowano i przebudowano $294 \mathrm{~km}$ autostrady, a najdłuższym ciągiem drogowym był odcinek Bielany Wrocławskie - Kleszczów długości 143 km. Wprawdzie łączył on Dolny Śląsk z Górnym Śląskiem, ale dochodził tylko do zachodnich granic aglomeracji górnośląskiej. Brakowało także przedłużenia autostrady do granicy z Niemcami. Na koniec 2004 roku w przebudowie był odcinek Krzywa - Bielany Wrocławskie, a w budowie Kleszczów - Sośnica. Jak wspomniano wcześniej, nie udało się na czas wyłonić podmiotu, którego zadaniem było przystosowanie autostrady do pobierania opłat. W rezultacie brakowało ważnych elementów infrastruktury, takich jak MOP-y czy stacje paliwowe. Według NIK powodowało to nie tylko utratę wpływów z eksploatacji autostrady, ale obniżało komfort podróżowania, było powodem dużej liczby wypadków drogowych, a także kradzieży mienia autostradowego ${ }^{44}$.

42 Statystyka. Autostrady i drogi ekspresowe, http://www.skyscrapercity.com/showthread.php?t= 345003 [dostęp: 12.02.2015].

43 A. Urbanik, Realizacja Programu budowy autostrad w Polsce, „Drogownictwo” 2001, nr 11, s. $329 \mathrm{i}$ nast.

44 NIK, Informacja o wynikach kontroli..., s. 55. 
Pod koniec stycznia 2005 roku ukończono trwającą 2,5 roku budowę 15,7-kilometrowego odcinka Sośnica - Chorzów Batory. Na inwestycję składały się dwie jezdnie po trzy pasy ruchu, częściowo zrealizowany węzeł na skrzyżowaniu z A1, węzeł Wirek i węzeł Chorzów Batory. Ze względu na wspomniane szkody górnicze jej koszt w przeliczeniu na $1 \mathrm{~km}$ sięgnął $52 \mathrm{mln}$ zł i był najwyższy w dotychczasowej historii budowy autostrad.

Tablica 1. Koszty budowy wybranych odcinków autostrady A4 do 2004 roku

\begin{tabular}{|l|c|c|c|}
\hline $\begin{array}{l}\text { Lokalizacja odcinka } \\
\text { autostrady }\end{array}$ & $\begin{array}{l}\text { Długość } \\
\text { odcinka }(\mathrm{km})\end{array}$ & $\begin{array}{l}\text { Wartość } \\
\text { kosztorysowa } \\
\text { (tys. zł) }\end{array}$ & $\begin{array}{l}\text { Koszt 1 km auto- } \\
\text { strady } \\
\text { (tys. zł) }\end{array}$ \\
\hline $\begin{array}{l}\text { Wrocław - } \\
\text { Nogowczyce }\end{array}$ & 126,2 & 1832561 & 14521 \\
\hline $\begin{array}{l}\text { Nogowczyce - } \\
\text { Kleszczów }\end{array}$ & 17,4 & 333001 & 19138 \\
\hline Kleszczów - Sośnica & 19,1 & 375274 & 19647 \\
\hline $\begin{array}{l}\text { Chorzów Batory - } \\
\text { Murckowska }\end{array}$ & 20,1 & 1124866 & 44963 \\
\hline Obejście Krakowa & 7,9 & 355063 & 444 \\
\hline
\end{tabular}

Źródło: NIK, Informacja o wynikach kontroli..., op. cit., s. 29.

Z końcem października 2005 roku oddano, liczący 19,1km, odcinek Kleszczów Sośnica. Powstały dwie jezdnie po dwa pasma ruchu z trzema węzłami. Dzięki tej inwestycji połączono istniejące odcinki Bielany Wrocławskie - Kleszczów i Sośnica Kraków. Pod koniec sierpnia 2006 roku zakończono trwającą od 2002 roku wymianę betonowej nawierzchni oraz przebudowę i wzmocnienie obiektów inżynierskich na trasie Krzywa - Bielany Wrocławskie. Otwarcie 92-kilometrowego odcinka umożliwiło korzystanie z 391-kilometrowego ciągu autostradowego Krzyżowa - Kraków. Istotnym mankamentem zachodniego odcinka A4 był brak, na znacznej długości, pasa awaryjnego, co znacznie obniżało bezpieczeństwo ruchu ${ }^{45}$.

Po trzyletnim zastoju w oddawaniu nowych inwestycji, w połowie sierpnia 2009 roku, autostrada A4 dotarła do granicy z Niemcami. Stało się to możliwe dzięki otwarciu odcinka węzeł Zgorzelec (Jędrzychowice) - Krzyżowa o długości 51,4 km. We wrześniu dobiegła końca rozbudowa węzła Murckowska w Katowicach i został otwarty kolejny, liczący 19,9 km, odcinek autostrady na wschód od Krakowa, który połączył węzły autostradowe Wielicka i Targowisko. Uzyskano dzięki temu ciąg autostradowy od granicy zachodniej do wschodniego wylotu A4 z Krakowa o długości $447 \mathrm{~km}$. Jego funkcjonowanie usprawniło oddanie do użytku w połowie $2010 \mathrm{roku}$

45 K. Jasiński, A4: Kleszczów - Sośnica, „Polskie Drogi” 2005, nr 10, s. XII; Archiwum GDDKiA 2005, www.gddkia.gov.pl [dostęp: 15.05.2015]; SISKOM, http://siskom.waw.pl/a4.htm [dostęp: 17.04.2015]; https://www.gddkia.gov.pl/userfiles/articles/a/autostrada-a4---zakonczenie-remo_3916// documents/a4_-modernizacja.pdf 
największego w kraju węzła autostradowego Sośnica na skrzyżowaniu autostrad A4 i A1. Otwarcie węzła nastąpiło z ośmiomiesięcznym opóźnieniem, do czego przyczyniła się powódź i problemy z wykupem gruntów.

Na początku września 2012 roku włączono do ruchu liczący 6,9 km odcinek między węzłami Rzeszów Północ a Rzeszów Wschód. Droga stanowiła pierwszy fragment autostrady A4 na terenie Podkarpacia. Pod koniec listopada udało się uruchomić z ograniczeniami 57-kilometrowy odcinek Szarów - Tarnów. Od węzła Targowisko do węzła Brzesko oraz od węzła Tarnów Zachód do węzła Tarnów Krzyż ruch puszczono dwiema jezdniami, zaś od Brzeska do węzła Tarnów Zachód jedną jezdnią. Ze względu na trwającą budowę uniemożliwiono przejazdy pojazdom powyżej 12 ton oraz występowały ograniczenia prędkości. Budowę drugiej jezdni między Brzeskiem a Tarnowem ukończono wiosną 2013 roku $^{46}$.

W końcu 2012 roku autostrada A4 liczyła $510 \mathrm{~km}$ i obejmowała najdłuższy ciąg autostradowy w Polsce - od granicy z Niemcami do Tarnowa - o długości $503 \mathrm{~km}$. Mimo hucznych zapowiedzi nie doprowadzono autostrady do granicy z państwem współorganizatorem Mistrzostw Europy w Piłce Nożnej - Ukrainąa ${ }^{47}$ Na przeszkodzie stanęły powodzie, przedłużające się badania archeologiczne, protesty ekologów i pojawiające się trudności finansowe, a przede wszystkim błędy w sferze przygotowań i wykonawstwa. Specjaliści drogowi wskazywali na poważne wady systemu i praktyki zamówień publicznych, których konsekwencją były bankructwa przedsiębiorstw wykonawczych.

W latach 2013-2016 stopniowo oddawano do użytku opóźnione odcinki. W maju 2013 roku samochody wjechały na 18-kilometrowy odcinek Jarosław Wschód - węzeł Przemyśl (Radymno). Od grudnia, kiedy oddano do użytku węzeł Jarosław Zachód, powstała możliwość korzystania z 25-kilometrowej autostrady Jarosław Zachód - węzeł Przemyśl. Pod koniec października otwarto 37-kilometrowy odcinek Dębica Wschód (wcześniej nazywany Dębica Pustynia) - Rzeszów Północ, zaś od 23 grudnia 2013 roku kierowcy mogli korzystać z 22-kilometrowego odcinka od węzła Przemyśl do Korczowej (granica państwa). Brakowało jednak węzła w Korczowej, który powstał w połowie czerwca 2014 roku. W końcu 2013 roku na końcowym, wschodnim fragmencie autostrady A4 możliwy był przejazd 50-kilometrowym odcinkiem od Jarosławia do granicy z Ukrainą. W ciągu autostradowym od granicy z Niemcami do granicy z Ukrainą brakowało 41-kilometrowego odcinka Rzeszów Wschód - Jarosław Zachód. Został on otwarty w lipcu 2016 roku, z pewnymi ograniczeniami ruchowymi, a roboty wykończeniowe przeciągnęły się do października. Zakończenie prac przy autostradzie A4 nastąpiło z czteroletnim opóźnieniem w stosunku do planów z 2007 roku $^{48}$.

Do 2016 roku autostrada A4, wbrew wcześniejszym planom, nie była w pełni odpłatna. Dnia 3 kwietnia 2000 roku wprowadzono opłaty na koncesjonowanym

46 J. Kaliński, Autostrady na EURO 2012, „Kwartalnik Kolegium Ekonomiczno-Społecznego. Studia i Prace" 2013, nr 1, s. 159.

47 Ibidem.

48 Archiwum GDDKiA 2013, 2016, www.gddkia.gov.pl [dostęp: 15.05.2015]; Oplaty za przejazd autostrada A4, „Drogownictwo” 2012, nr 7-8, s. 276. 
odcinku Katowice - Kraków, które objęły wszystkich użytkowników. Na odcinkach budowanych w systemie tradycyjnym od 1 lipca 2011 roku stopniowo wprowadzano opłatę w systemie elektronicznym viaTOLL, obejmującą pojazdy o wadze od 3,5 tony. Samochody osobowe i motocykle zostały objęte opłatą od 1 czerwca 2012 roku na 160-kilometrowym fragmencie od Bielan Wrocławskich do Sośnicy ${ }^{49}$.

\section{KONKLUZJA}

Budowa autostrady A4 trwała od 21 marca 1934 roku, kiedy podjęto prace między Legnicą a Wrocławiem, do 20 lipca 2016 roku, kiedy zakończono budowę odcinka od Rzeszowa do Jarosławia. Realizacja magistrali drogowej od granicy z Niemcami do granicy z Ukrainą nastąpiła w warunkach wielkich zmian politycznych i ekonomicznych na terenach, przez które przechodzi jej korytarz. Do 1945 roku budowana była jako niemiecka autobahn łącząca Berlin z Górnym Śląskiem. Po wojnie, już w granicach Polski, powstawała początkowo jako połączenie Dolnego i Górnego Śląska z Krakowem, a następnie jako południowy szlak tranzytowy między Niemcami a Ukrainą. Ostateczny przebieg autostrady silnie związany był z przemianami politycznymi w Europie po 1989 roku, a zwłaszcza z przystąpieniem Polski do Unii Europejskiej. Na przyspieszenie inwestycji na przełomie XX i XXI wieku zasadniczy wpływ wywarło ustalenie paneuropejskich korytarzy transportowych i zasilenie polskiego drogownictwa unijnymi środkami finansowymi.

\section{BIBLIOGRAFIA}

Archiwum GDDK i A (różne lata), www.gddkia.gov.pl.

Archutowski E.W., Drogi publiczne i ich finansowanie, ,Drogownictwo” 2001, nr 11.

AS, Wykup gruntów pod autostrady, „Polskie Drogi” 2005, nr 10.

Autostrada A4: żyła zlota w krwiobiegu gospodarki, http://www.rynekinfrastruktury.pl/ wiadomosci/autostrada-a4-zyla-zlota-w-krwiobiegu-gospodarki-55640.html [dostęp: 1.08.2017].

Badora K., Autostrada - środowisko przyrodnicze. Studium konfliktów przestrzennych na przyktadzie opolskiego odcinka autostrady A-4, Opole 2004.

Borecka-Smolińska E., W pięć godzin od granicy do granicy, „Cash” 1994, nr 6.

Budowa autostrady A4 na terenie oddziału Katowice, „Magazyn Autostradowy” 2003, nr 6.

49 „Motofakty”, http://www.motofakty.pl/artykul/oplaty-za-przejazd-autostrada-a4-z-wroclawia-do-gliwic-mapa-cennik.html [dostęp: 17.05.2015]; Autostrada A4: żyła złota w krwiobiegu gospodar$k i$, http://www.rynekinfrastruktury.pl/wiadomosci/autostrada-a4-zyla-zlota-w-krwiobiegu-gospodarki55640.html [dostęp: 1.08.2017]. 
Chrostowska H., Studia ekonomiczne budowy autostrad w Polsce, „Drogownictwo” 1992, nr 9.

Commission of the European Communities, Trans-European Networks: Towards a Master Plan for The Road Network and Road Traffic, Brussels-Luxembourg 1992.

Dobrodziej E., Realizacja Programu budowy autostrad, „Polskie Drogi” 1995, nr 11.

Grzegrzółka K., Autostrady. W tym roku zacznie się wykupywanie gruntów, „Rzeczpospolita" 1996, 13.06.

Jarucka A., Pierwsze koncesje, „Autostrada” 1997, nr 2, s. 6.

Jasiński K., A4: Kleszczów - Sośnica, „Polskie Drogi” 2005, nr 10.

Jaw orski Z., Program budowy autostrad w Polsce 1993-2007, „Drogownictwo” 1993, nr 9. JR, Autostrada nad kopalniami, „Polskie Drogi” 2003, nr 12.

Kaliński J., Autostrady na EURO 2012, „Kwartalnik Kolegium Ekonomiczno-Społecznego. Studia i Prace" 2013, nr 1.

Kaliński J., Autostrady w Polsce, czyli drogi przez mękę, Łódź 2011.

Kaliński J., Historia polskich autostrad (2), „Autostrada” 1997, nr 11.

Kaliński J., Historia polskich autostrad (4), „Autostrada” 1998, nr 1.

Kaliński J., Historia polskich autostrad (5), „Autostrada” 1998, nr 2.

Kostuch R., Góra Świętej Anny i autostrada, „Aura” 1996, nr 7.

Koziarski S., Autostrady w Europie $i$ w Polsce, „Przegląd Komunikacyjny” 1996, nr 7-8.

Koziarski S., Przekształcenia infrastruktury transportowej w Polsce, Opole 2010.

Kozłowska M.K., Oranowska A., Drogowe spółki specjalnego przeznaczenia, „Przegląd Komunikacyjny" 2016, nr 8.

Madeyski A., Autostrada Kraków - Chrzanów, „Drogownictwo” 1984, nr 7.

Majchrzak K., Uchnyst M., Modernizacja autostrady a-4 odcinek Legnica - Wroctaw, „Drogownictwo” 1995, nr 5.

Markowski A., Drogownictwo w 1978 r., „Drogownictwo” 1978, nr 3.

Ministerstwo Infrastruktury, Program budowy dróg krajowych i autostrad na lata 2002 2005, Warszawa 2002.

Ministerstwo Infrastruktury, Raport z realizacji Programu budowy dróg krajowych $i$ autostrad, Warszawa 2004.

Ministerstwo Transportu i Gospodarki Morskiej, Program budowy autostrad w Polsce, Warszawa 1993.

„Motofakty”, http://www.motofakty.pl/artykul/oplaty-za-przejazd-autostrada-a4-z-wroclawia-do-gliwic-mapa-cennik.html [dostęp: 17.05.2015].

NIK, Informacja o wynikach kontroli budowy autostrad w Polsce, Warszawa 2003.

Optaty za przejazd autostrada A4, „Drogownictwo” 2012, nr 7-8.

Pierwsza koncesja dla Stalexportu, „Rzeczpospolita” 1997, 30 stycznia.

Poniatowska-Jaksch M., Autostrada a rozwój lokalny, Warszawa 1997.

Prace Rady Motoryzacyjnej 1958-1964, Warszawa 1965.

Program rzeczowo-finansowy dla inwestycji drogowych realizowanych $z$ wykorzystaniem środków Krajowego Funduszu Drogowego na lata 2005-2006, „Biuletyn Informacyjny Drogownictwa" 2005, nr 1.

Przetargi na budowe autostrad, „Polskie Drogi” 1996, nr 2.

Realizacja programu budowy autostrad, „Polskie Drogi” 1996, nr 6.

Reichel C., Drogi na Dolnym Śląsku. Takie byty początki, „Polskie Drogi” 1995, nr 8.

Serbreńska A., Nowy rząd - nowy program drogowy, „Polskie Drogi” 2002, nr 3.

SISKOM, http://siskom.waw.pl/a4.htm [dostęp: 17.04.2015]. 
Słotwiński D., Sybilski D., Czy jesteśmy technicznie przygotowani do budowy autostrad, „Drogownictwo” 1994, nr 11.

Stalexport Autostrada Małopolska S.A. - koncesjonariusz płatnego odcinka autostrady A4 Katowice - Kraków, http://sam.autostrada-a4.com.pl/o_firmie/historia_stalexport [dostęp: 10.04.2015].

Statystyka. Autostrady $i$ drogi ekspresowe, http://www.skyscrapercity.com/showthread. php?t=345003 [dostęp: 12.02.2015].

Stefańska A., Poczekamy na autostrady, „Rzeczpospolita. Ekonomia \& Rynek” 2012, 28 czerwca.

Stol, A-4 w Katowickiem, „Autostrada” 1998, nr 2.

Strategia rozwoju infrastruktury transportu na lata 2004-2006 i dalsze, „Drogownictwo” 2003, nr 10.

Studium Planu Krajowego II, Warszawa 1948.

Suchorzewski W., Program budowy autostrad a rozwój ekologicznie zrównoważony, „Drogownictwo" 1995, nr 5.

Świątecki P., Ustawa o autostradach płatnych, „Przegląd Komunikacyjny” 1995, nr 2.

Talunas E., Historia finansowania drogownictwa polskiego, „Drogownictwo” 2006, nr 2.

Uchwały IV-go Polskiego Kongresu Drogowego, „Wiadomości Drogowe” 1938, nr 132-133.

Urbanik A., Realizacja Programu budowy autostrad w Polsce, „Drogownictwo” 2001, nr 11. 